\title{
小児頭部外傷の現状と課題
}

\author{
荒木 尚 ${ }^{1)}$, 熊井戸 邦佳 ${ }^{1)}$, 大宅 宗—2), 庄島 正明 ${ }^{2)}$ ，松居 徹 ${ }^{2)}$ \\ 1）埼玉医科大学総合医療センター高度救命救急センター，2）埼玉医科大学脳神経外科
}

\section{Pediatric Traumatic Brain Injury : Current Status and Issues}

\author{
Takashi Araki, M.D., Ph.D. ${ }^{1)}$, Kuniyoshi Kumaido, M.D., Ph.D. ${ }^{1)}$, Soichi Oya, M.D., Ph.D. ${ }^{2)}$, \\ Masaaki Shojima, M.D., Ph.D. ${ }^{2)}$, and Toru Matsui, M.D., Ph.D. ${ }^{2)}$ \\ 1) Department of Emergency and Critical Care Medicine, Saitama Medical Center, Saitama Medical University, 2) Depart- \\ ment of Neurosurgery, Saitama Medical Center, Saitama Medical University
}

Traumatic brain injury is one of the most frequent causes of morbidity and mortality in children. Even after appropriate treatment, the impact of traumatic brain injury on a child's life can be long-lasting and devastating. Higher brain dysfunction is likely to interfere with academic performance, impair healthrelated quality of life, and lead to mental health problems. However, the pathophysiological features specific to pediatric traumatic brain injury remain largely unexplored, and there are few clinical studies with a high level of evidence or basic studies that take into account the growth and development of the central nervous system. International efforts are required to clarify pediatric-specific findings without linearly transferring adult data. To elucidate the current status and issues of pediatric head injury, we will introduce the latest findings on acute care and the most important points of the "Guidelines for the Management of Pediatric Severe Traumatic Brain Injury, Third Edition." In addition, we will discuss the latest issues related to the diagnosis of abusive head trauma, which has become a serious social problem on a global scale, and treatment options for abusive head trauma.

(Received March 3, 2021 ; accepted April 6, 2021)

Key words : traumatic brain injury, children, guidelines, abusive head trauma, intracranial pressure monitoring

Jpn J Neurosurg（Tokyo） $30: 450-461,2021$

\section{小览重症頭部外傷治療 ガイドライン第 3 版 ${ }^{33}$ 一改訂の要点一}

\section{1 概要}

2019 年 Pediatric Critical Care Medicine Supplement にお いて Brain Trauma Foundation（BTF）小児重症頭部外傷 治療ガイドライン第 3 版が公表された ${ }^{33)}$. 2012 年第 2 版 の改訂であり ${ }^{31}$, 「チームアプローチの理念」を反映させ た学術的かつ実践的な知見の集約である。初版は Chi- cago 研究グループにより作成され，その後最新の医学的 根拠に即したガイドラインを提供する努力が行われてき た。今回成人ガイドライン $(2017$ 年 1 月発行 $)$ や病院前 治療ガイドライン (近日発行) など BTF の 3 ガイドライ ン改訂事業の一環となる小児ガイドライン改訂であり, 重症例に対する治療の最適化を通し転帰改善を目標とし たものである．合計 48 の新知見が含まれたが，いずれも エビデンスレベルは低く，レベル I 推奨の根拠となる無 作為化試験は存在せず，レベル II が 3 件，その他はレベ

\footnotetext{
連絡先：荒木 尚 干 350-8550 川越市鴨田 1981 埼玉医科大学総合医療センター Address reprint requests to: Takashi Araki, M.D., Ph.D., Department of Emergency and Critical Care Medicine, Saitama Medical Center, Saitama Medical University, 1981 Kamoda, Kawagoe-shi, Saitama 350-8550, Japan
} 
ルIIIであった

今回ガイドライン改訂に加え, 治療抵抗性の頭蓋内圧 克進に対する治療 (first-tier therapy/second-tier therapy) のパスとして「アルゴリズム」が新たに示された ${ }^{32}$. こ のアルゴリズムは, 本ガイドラインのエビデンスに基づ く推奨と, エビデンスが得られないため委員会全体で検 討されたコンセンサスに基づくエキスパートオピニオン の両方が反映されている，従来のガイドラインには示さ れなかったテーマも複数登場し, 今後の研究が必要であ る。頭蓋内圧（intracranial pressure：ICP）充進に対する stepwise approach, 患者状態による治療介入夕イミング の違い, 迅速な治療介入が必要となるシナリオ, multimodal monitoring における各モニタリング目標の統合, 治療の最小目標と最適目標, 治療漸減の考え方などが網 羅されている. 当ガイドラインはThe Approaches and Decisions in Acute Pediatric TBI Trial $(\mathrm{ADAPT})^{7) 8) 36)}$ の終 了と同時期に作成されたが, ADAPT は小児重症頭部外 傷 1,000 例の登録を完了した重要な研究である. 小児頭 部外傷については, 脳損傷の重症度スペクトル, 脳振盪 の高い有病率, 外傷性脳損傷の新たな分類作成, 新たな 研究デザインの必要性などに関する議論を背景に注目が 高まりつつある。この章では, ガイドライン改訂第 3 版 の要点を示し解説する.

査読対象の文献検索基準として, 重症頭部外傷 〔Glasgow Coma Scale（GCS）スコア3〜8 と定義〕の小 児患者 (年齢 18 歳以下) が研究対象となり, アウトカム (死亡率, 神経学的機能, またはテーマに即した中間アウ トカム) が評価された研究を主に収集した。査読者 2 名 が独立して対象を決定し, 判断が相違する場合は統合あ るいは第 3 査読者の判断に準拠した。 2010 年〜2017 年 6 月までに発表された研究が追加され, 推奨決定には Class 1〜3 の研究結果を用い, エビデンスの質および適 用可能性が考慮されている. 適切なエビデンスがない項 目について推奨は行わず，レベルの弱い論文 (resultの 一貫性や正確性の欠如）も推奨の根拠として用いられて いない. 今回の改訂版には 22 推奨が存在し, うち 9 項が 新規あるいは大幅に改訂された。レベル I 推奨はなく, レベル II 推奨が 3 項, レベルIII推奨が 19 項となった。こ こではレベル II 推奨であるモニタリング，治療閾值，治 療についておのおの解説する.

\section{2 改訂の要点}

\section{1. モニタリングに関する推奨}

モニタリング自体は治療結果に直接影響を与えない が，モニタリングから得られる情報は治療方針決定にき
わめて有用である。モニタリングにより得られたデータ に基づき実施された治療は，モニタリングのない治療よ り良好な転帰をもたらす可能性が高い.

ICP モニタリング, advanced cerebral monitoring $(\mathrm{ACM})$, 神経画像検査 (neuroimaging) の 3 種類のうち ICP と ACM に関する記載は第 2 版と変更はない. 今回 の改訂では, ICP モニタリングの使用（レベルIII）, ACM として脳組織酸素分圧 (partial pressure of brain tissue oxygen : $\left.\mathrm{PbrO}_{2}\right)$ モニタリングを使用する場合 $>10 \mathrm{mmHg}$ を維持する(レベルIII)ことが新たに推奨された。なお， (1)予後改善のため $\mathrm{PbrO}_{2}$ モニタリングを推奨する十分な エビデンスは存在しない. (2)ACM（脳内酸素化）は, 凝 固異常など侵襲的モニタリングの禁忌がなく, 脳死診断 を受けていない患者にのみ行うよう追記された。神経画 像検査については, 従来の推奨に加え, 「ICP 克進疑いを 除外する目的の CT 検査は推奨されない」と記載された (レベルIII).

\section{2. 治療閾値に関する推奨}

小児重症頭部外傷のモニタリング変数の閾值に関連し た推奨であり, 特に ICP と脳灌流圧 (cerebral perfusion pressure : CPP) について記載された. ICP 治療の目標閾 值は $20 \mathrm{mmHg}$ (レベルIII), CPP 治療の目標閾值は 40 $\mathrm{mmHg}$ (レベルIII）が推奨され，CPP $40 \mathrm{mmHg}$ 維持をよ り確かにするために CPP 40〜 $50 \mathrm{mmHg}$ の維持が推奨さ れる。 また乳幼児ではより低く, 思春期ではより高い年 齢特異的な治療閾值を定めてもよい，と記載された。

\section{3. 治療に関する推奨}

治療に関する推奨は 10 項あり, 小児頭部外傷に特化 した内容とリスクについて言及している. 現在主流とさ れる治療法でありながら新しい手法が登場し改変が望ま しいものについては, 既存の記載に変更または追記がな された。推奨は全 15 項, うち 7 項が新規または改訂され た. 抗浸透圧利尿薬に関する推奨 2 項, 鎮痛・鎮静薬, 神経筋遮断薬に関する推奨 1 項, 痤攣予防に関する推奨 1 項，体温調節に関する推奨 2 項，および栄養学に関す る推奨 1 項である. 今回の改訂では新規または既存の推 奨を支持するため使用されたエビデンスベース 35 件の 新規研究が追加された。各治療法における推奨について 要点を述べる.

\section{1）高浸透圧治療}

ICP 亢進の治療には高浸透圧食塩水 $(3 \%)$ の急速投与 が望ましい，緊急の際有効な容量として $2 \sim 5 \mathrm{ml} / \mathrm{kg}$ を 10〜20 分かけて投与する（レベル II ）.

高浸透圧食塩水の持続投与に $3 \%$ 食塩水を用いる際, $0.1 \sim 1.0 \mathrm{ml} / \mathrm{kg}$ の用量でスライディングスケールを用い 
調節する. ICP $20 \mathrm{mmHg}$ 以下を維持できる最少量がよい （レベルIII）。治療抵抗性の ICP 六進の場合には $23.4 \%$ 高 張食塩水の急速投与を行う。 $0.5 \mathrm{ml} / \mathrm{kg}$ を $30 \mathrm{ml}$ 上限とし て投与する（レベルIII）。

高浸透圧治療すべてに共通することとして，血漿 $\mathrm{Na}$ 濃度 $170 \mathrm{mEq} / l$ 以上が遷延し血小板減少や貧血を誘発し ないよう注意する。また血漿 $\mathrm{Na}$ 濃度 $160 \mathrm{mEq} / l$ 以上の 遷延では深部静脈血栓症の発生率が高まる。マニトール は頻用される薬剤であるが, 有効性に関する明らかな医 学的根拠はなく慣習的な投与として位置付けられた。

\section{2）鎮痛薬，鎮静薬，神経筋遮断薬}

ICP 治療目的に鎮痛・鎮静薬を使用する際, ICP が危 機的状態では脳灌流低下を誘発する危険がある。このた めミダゾラムやフェンタニルの急速注射は避ける（レベ ル III)，鎮痛・鎮静・筋弛緩薬の適応，選択や投与量につ いては明確なデータがないため主治医の判断に委ねられ る。米国食品医薬品局 (FDA) 勧告に基づき, 鎮静や ICP 治療を目的としたプロポフォールの持続投与は遷延して はならない。

\section{3）脳脊髄液ドレナージ}

ICP 克進の治療に脳室ドレナージによる髄液排出は有 効である(レベルIII).

\section{4）病攣予防（症候性あるいは非症候性）}

外傷後性早期痓攣（7 日以内）の発生低下には，抗痙 攣薬を投与すべきである(レベルIII)。早期痤攣の予防効 果や合併症の観点においてフェニトインに対するレベチ ラセタムの優位性は実証されていない.

\section{5）人工呼吸管理}

受傷後 48 時間以内は $\mathrm{PaCO}_{2}<30 \mathrm{mmHg}$ とする予防的 高度過換気は行わない（レベルIII）。治療抵抗性 ICP 立 進に対する治療として高度過換気を実施する際は, 脳虚 血評価のため $\mathrm{ACM}$ を行うとよい（レベルIII）.

\section{6) 体温管理 $\cdot$ 低体温}

中等度低体温 $\left(32 \sim 33^{\circ} \mathrm{C}\right)$ は予後改善目的に実施すべ きでない（レベル II）。一方，ICP 方進に対する中等度低 体温 $\left(32 \sim 33^{\circ} \mathrm{C}\right)$ は効果が期待できる（レベル III )。ただ し, 復温は $12 \sim 24$ 時間に $0.5 \sim 1.0^{\circ} \mathrm{C}$ の割合で行い, 合併 症防止が重要である。また, 低体温中にフェニトインを 使用する場合は，中毒域に入らないよう復温期血中濃度 モニタリングを行う。

\section{7）バルビツレート療法}

高用量バルビツレート療法は, 内科的・外科的治療が 奏効しない ICP 克進に対し, 循環動態が安定している場 合に行うとよい (レベルIII)。 ICP 克進に対し高用量バル ビッレート療法を行う際は, 適切な $\mathrm{CPP}$ を維持するため
呼吸循環管理が必須であり持続動脈圧モニタリングを行 う。

\section{8）減圧開頭術}

減圧開頭術は, 神経学的所見の増悪, 脳ヘルニア症状, 内科的治療が無効な ICP 六進を呈する場合実施してもよ い（レベルIII）.

\section{9）栄養管理}

免疫調整食は使用されない（レベル II ）。一方, 早期の 経腸栄養サポート開始（受傷 72 時間以内）は, 死亡率減 少, 転帰改善の効果が示唆されている（レベルIII）.

\section{0）ステロイド療法}

副腎皮質ステロイドは, 転帰改善や ICP 減少には有効 でない(レベルIII)。ただし慢性的ステロイド補充療法を 必要とする患者, 副腎抑制を受けた患者, および視床下 部一下垂体系の障害に対する副腎皮質ステロイド補充を 否定するものではない.

\section{3 小肾重症頭部外傷の治療アルゴリズム}

今回の改訂では新たにアルゴリズムが設けられ視覚的 に理解しやすい指針となった（Fig. 1, 2)。来院時 GCS 8 あるいはそれ未満の意識レベルにある患者を重症と定義 する. 外傷初期診療において頭部 CT を行い, 緊急開頭 術の適応ではない場合, 神経集中治療の pathwayに進む. ICU 管理は ICP 值を基準に行われ脳実質内センサー留置 を原則とする。

\section{Baseline care}

小児重症頭部外傷患者に対して適用される 9 つの治療 原則が baseline care である.

(1)鎮静薬・鎮痛薬の適正量を維持する：ミダゾラム・ フェンタニルを併用する。

(2)調節呼吸: $\mathrm{PaO}_{2}$ 90 100 mm Hg, $\mathrm{PaCO}_{2} 35 \sim 40$ $\mathrm{mmHg}$ の維持

(3)正常深部体温の維持と発熱予防および治療： $38^{\circ} \mathrm{C}$ 以 下へ調節する。

(4)適正な血管内容量の確保: 中心静脈圧 (central venous pressure : CVP) や尿量, BUN などを指標と する. $\mathrm{Na} 140 \mathrm{mEq} / \mathrm{l}$ 以上の維持，乳幼児は $5 \% \mathrm{dex}$ trose を用い低血糖への配慮が必要。年長児には生 理食塩水が望ましい，栄養投与開始は受傷から 72 時間以内が望ましい.

(5)血液量 (hemoglobin 值)維持: 最低 $7 \mathrm{~g} / \mathrm{d} l$ を維持する.

(6) 凝固異常の治療: $\mathrm{ICP}$ センー・ $\mathrm{PbrO}_{2}$ プローブの挿 入前が理想的であるが, 過剩な治療は凝固異常を増 悪させるため, 出血状態を参考に検討する.

(7)頭位挙上した頭部正中固定：頭部は正中固定のう 


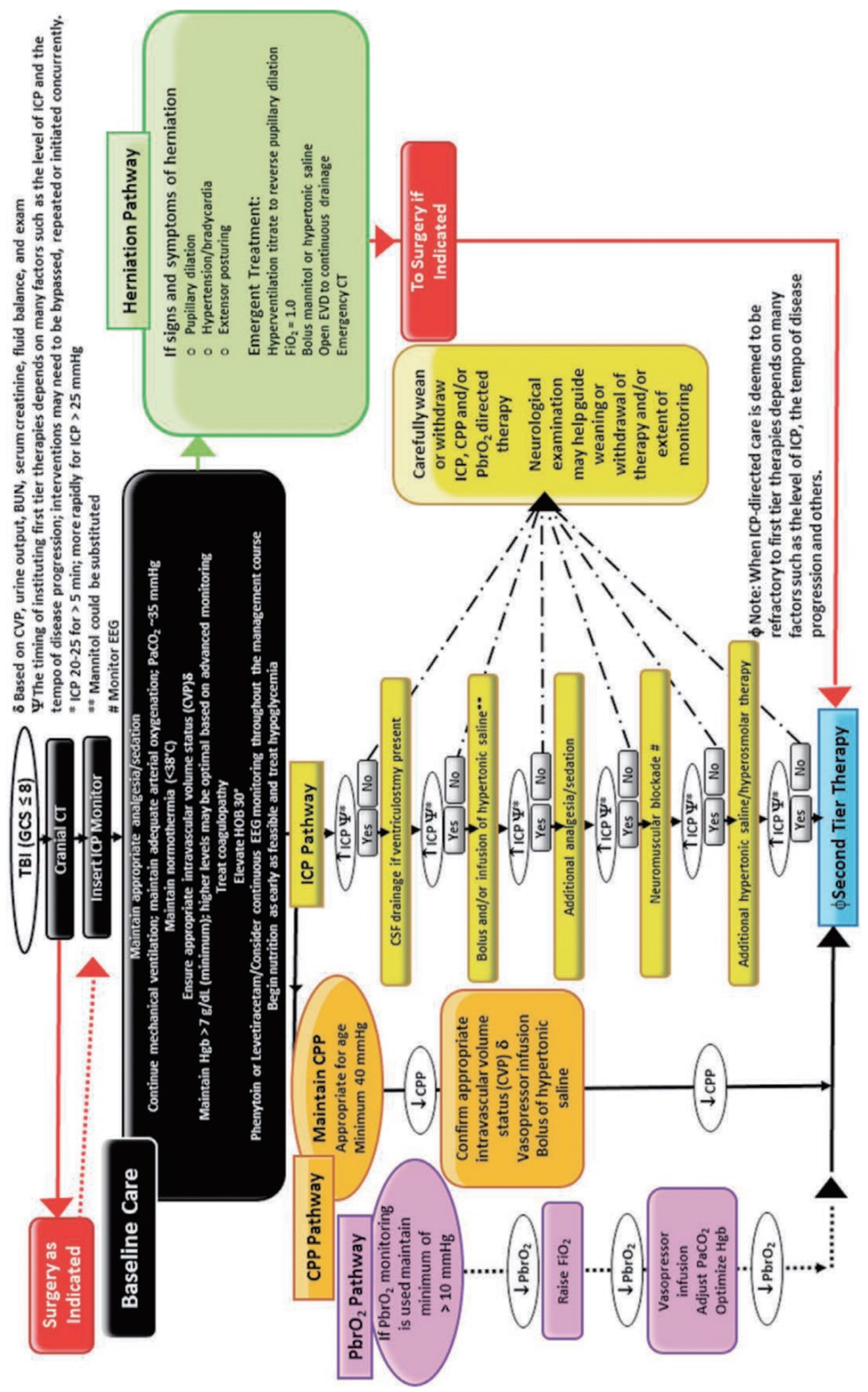

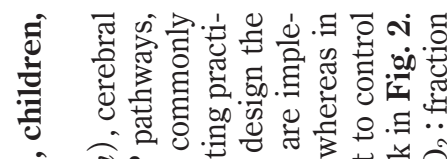

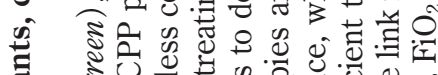

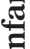

bo 0 .

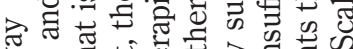

ㅋ.

获

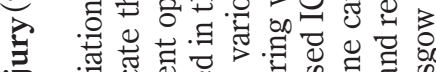

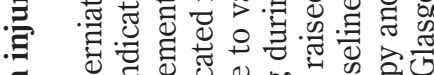

看

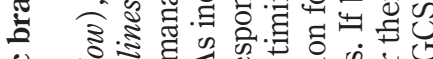

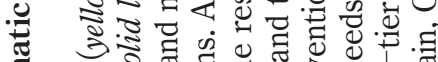

त क 00.

농

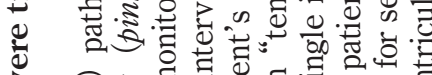

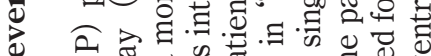

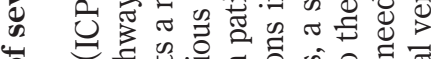

प

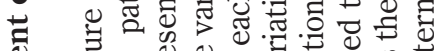

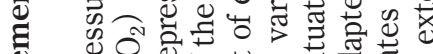

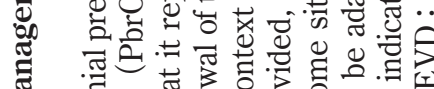

趼

(

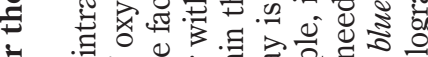

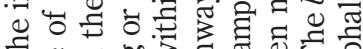

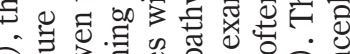

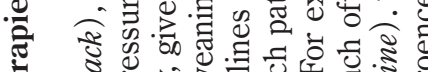

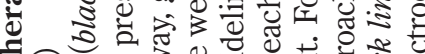

可 可

可啳

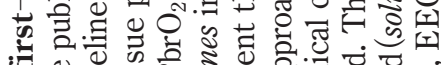

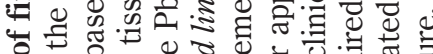

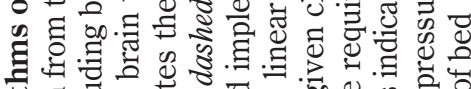

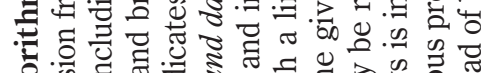

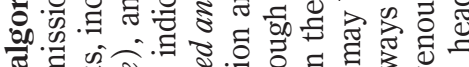

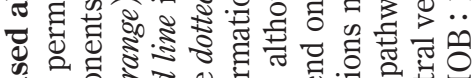
of : I

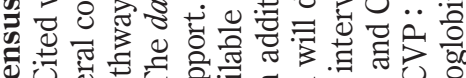

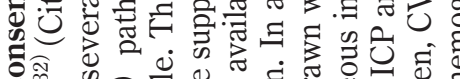

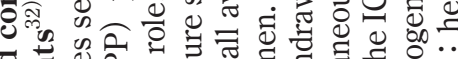

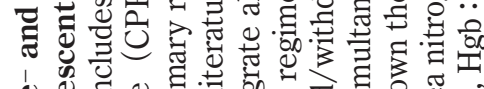

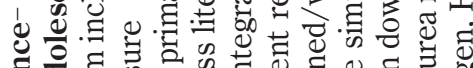

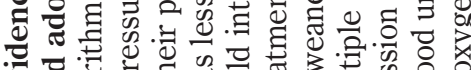

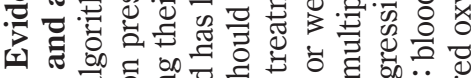

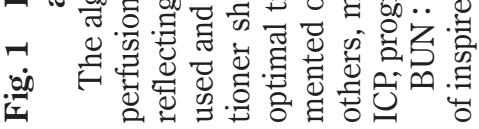




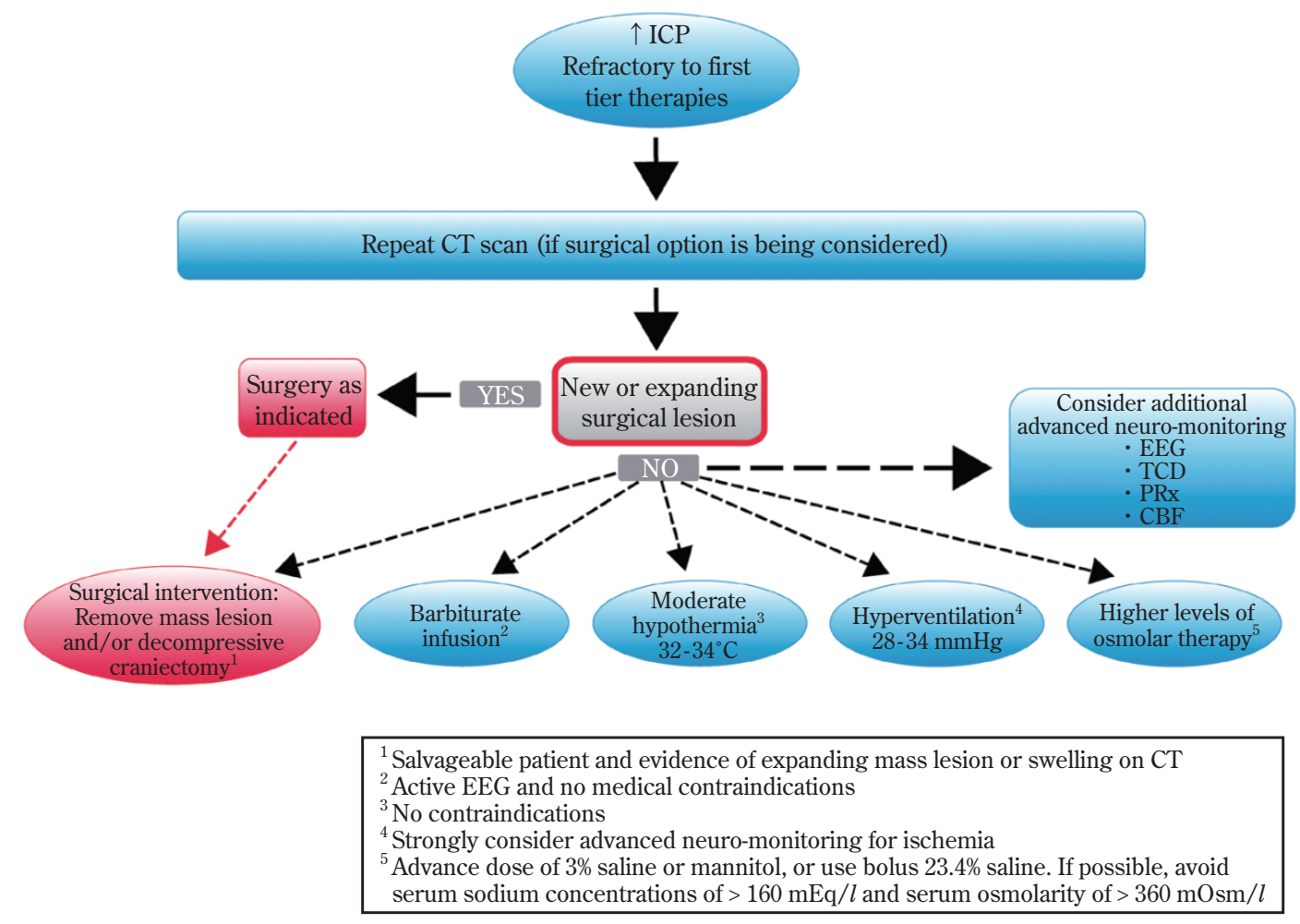

Fig. 2. Evidence- ${ }^{-}$and consensus-based algorithms of second-tier therapies for the management of severe traumatic brain injury in infants, children, and adolescents ${ }^{32)}$ (Cited with permission from the publisher)

The algorithm is linked to the first-tier therapy algorithm (Fig. 1) and represents the treatment options for refractory intracranial hypertension when tier 1 approaches are inadequate. These therapies may be applied singly, serially, or in combination. In addition, the management of refractory intracranial hypertension in the second-tier phase may be aided by the use of advanced monitoring. Please see the text for further details.

$\mathrm{CBF}$ : cerebral blood flow, EEG : electroencephalogram, ICP : intracranial pressure, PRx : pressure reactivity index, TCD : transcranial Doppler ultrasonography

え, 30 度挙上する.

8)抗㾏攣薬の使用と持続脳波モニタリング : 抗瘆攣薬

の種類や用量について具体的推奨はないが，レベチ

ラセタムは他剤に比較して使用しやすい。筋弛緩薬

を使用する際には持続モニタリングが有用である。

(9)栄養投与開始：低血糖に注意し可能なかぎり早期か ら開始する。

\section{First-tier therapy}

First-tier therapy として, (1)ICP 元進に対する治療, (2) CPP 異常に対する治療, (3) $\mathrm{PbrO}_{2}$ 異常に対する治療, 以上 3 種の pathway を含む (Fig. 1).

\section{1) ICP pathway}

全年齢において ICP $20 \mathrm{mmHg}$ 以上を治療閾值とし, 20 $\mathrm{mmHg}$ 以上が 5 分以上持続した場合治療介入を行う。 ICP 值が 20〜 $25 \mathrm{mmHg}$ 程度であれば, 段階的に first-tier therapyを試みる。最初に脳室ドレナージにて髄液排出
を行い, 無効またはドレナージがない場合, 高張食塩水 の bolus 投与を行う。高張食塩水の代わりにマニトール を使用してもよい．繰り返し投与可能だが，高張食塩水 は $360 \mathrm{mOsm} / l$, マニトールは $320 \mathrm{mOsm} / l$ を血液浸透圧 の上限として投与量を調節する。 さらに無効な場合, 鎮 静鎮痛薬の用量を追加し, 筋弛緩薬投与を考慮する. 血 液ガス, 電解質, クレアチニン, へモグロビンを測定し, 平均動脈圧, 体温, 呼気終末炭酸ガス濃度を経時的に記 録する. First-tier therapy が無効とされた場合, secondtier therapy に進む.

\section{2) CPP pathway}

ICP 值が上昇しても， CPP 值は正常に維持されている ことが多い. CPP 值は最低 $40 \mathrm{mmHg}$ の維持が重要で, 年齢により 40〜 $50 \mathrm{mmHg}$ の治療幅に設定するとよい. 脳低灌流や虚血を予防する目的で，より高い值に維持す ることもある。 CPP 值の維持には適正な血管内容量の補 
充が大切であり, CVP 4 $10 \mathrm{mmHg}$ を適正とする. 平均 動脈圧 (mean arterial pressure: MAP) 值は補液を十分に 行い正常容量に保つ. ICP 值と CPP 值は連動するが, 高 張食塩水を使用すると, ICP 值降下と CPP 值正常化が同 時に得られる。一方, 鎮静鎮痛薬を用いる場合, ICP 值 が降下しても心抑制などにより CPP 值が正常化しない こともある。

\section{3) $\mathrm{PbrO}_{2}$ pathway}

$\mathrm{PbrO}_{2}$ モニターの使用経験が集積され, 新たな pathway として追加された。最低值を $10 \mathrm{mmHg}$ と設定し, $\mathrm{FiO}_{2}$ 上昇や昇圧薬を用いた $\mathrm{MAP}$ 值の上昇, $\mathrm{PaCO}_{2}$ 上昇 による脳血流増加, 輸血によるへモグロビン值上昇等を 通して最適化を図る（日本では $\mathrm{PbrO}_{2}$ の測定は未承認で ある)。

\section{Second-tier therapy}

First-tier therapy が無効な ICP 六進や, CPP 值・ $\mathrm{PbrO}_{2}$ 值の異常に対しさらなる治療介入が必要と考えられた場 合, second-tier therapy を考慮する (Fig. 2)。まず手術的 除去が可能な病変の有無を確認するため CT 行う.

Second-tier therapy には, より侵襲性の高いモニタリン グが必要である。外科的治療として減圧開頭術が最もよ く行われるが, 開頭部位や硬膜形成, 血腫除去は状況に 応じ選択される。内科的治療として, バルビッレート療 法, 中等度低体温, 治療的過換気, 高度の浸透圧療法の 4 種類について記載されている。 また侵襲的モニタリン グ, 治療の漸減について言及している.

\section{1）バルビツレート療法}

ペントバルビタールが最も多く用いられる。他の治療 が無効で ICP $25 \mathrm{mmHg}$ 以下に維持できない場合適用さ れる。治療効果が認められない場合, 減圧開頭術やその 他の second-tier therapy を追加する. ICP $20 \mathrm{mmHg}$ 以下 が 24 時間以上維持できた場合，24〜 96 時間かけて漸減 する。適正 $\mathrm{CPP}$ 值の維持に昇圧薬を用いることもある.

\section{2）中等度低体温療法}

受傷早期の中等度低体温 $\left(32 \sim 33^{\circ} \mathrm{C}\right.$ あるいは 34 $\left.35^{\circ} \mathrm{C}\right)$ 療法の有効性は否定されたが, ICP 元進の治療と して, 晚期中等度低体温療法が有効とする報告が多い.

\section{3）治療的過換気と浸透圧療法}

$\mathrm{PaCO}_{2}$ 值 15〜30 mmHg とする高度過換気は, 晚期ある いは治療困難な ICP 充進に対する治療とされてきた。低 炭酸ガス血症の程度に合わせ血中 $\mathrm{Na}$ 濃度, 血漿浸透圧, 鎮痛鎮静薬用量を調節する治療もある.

\section{4）侵襲的モニタリング}

モニタリングは治療の調整具合を可視化するため重要 である. $\mathrm{PbrO}_{2}$ モニタリング, 持続脳波, 経頭蓋ドップ
ラー超音波， pressure reactivity index（PRx）などがあ る. 例として $\mathrm{PbrO}_{2}$ モニタリングにより過換気が組織酸 素分圧を低下させたか判断が可能となる。PRxは急性期 ICP と平均血圧の相関係数であり, 理想的 CPP 值を判断 する指標として有用である。

\section{5）治療の漸減}

パラメータが正常化し 12〜24 時間安定した場合, 治 療の漸減を検討する。画像所見や時間経過や重症度など 個別に判断されなくてはならない.

\section{4 ガイドラインに準拠した治療の応用}

The Approaches and Decisions in Acute Pediatric Traumatic Brain Injury (ADAPT) Trial は米国 National Institute of Neurological Disorders and Stroke (U01 NS081041) 研 究費を基に米国，英国，スペイン，オランダ，インド， 南アフリカ共和国，オーストラリア，ニュージーランド の 51 施設より 1,000 名の小児頭部外傷患者を登録, 有効 な治療戦略を検討した研究である ${ }^{7)}$. 厳密な観察研究で あり 18 歳以下, 意識レベル GCS 8 あるいはそれ以下の 重症例, ICPセンサー挿入例を対象とし妊婦を除外した. Miller-Ferguson ら ${ }^{42}$ は当初 200 例を対象とし虐待による 頭部外傷の特徴や死亡率, 治療に関して検討した。その 結果，若年，女児に多い傾向にあり，痤攣や無呼吸を伴 いやすいことが示された。虐待例は著しい ICP 克進を認 め, ICP モニタリングとガイドライン準拠の治療により 効果が期待できることを示した。

ICP モニタリングに関する Chesnut ら $^{12)}$ のランダム化 比較試験に小児例は含まれておらず，また ICP モニタリ ングと転帰の相関について検討したエビデンスレベルの 高い臨床研究は少ない. ICP モニタリングの有効性が示 された研究には, 複数の治療により ICP 降下し転帰が改 善した ${ }^{3)}, 100$ 例の前向き観察により, ICP 降下と治療 1

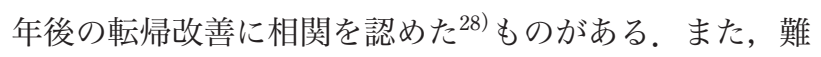
治性 ICP 克進例は ICP 最大值にかかわらず予後絶対不良 と結論した後方視的研究もある ${ }^{4)}$.

モニタリングを駆使した治療方針決定には，正しい データの理解が不可欠である. 現在 ICP 六進を示す画像 診断法やバイオマーカーは存在しないため, ICP モニ夕 リングはICP 克進を明確に唯一提示できる方法である。 頭部外傷治療の基本理念がICP 元進の予測と抑制にある 以上，モニタリングによる ICP 充進の早期検出と適切な 治療介入は必須である。長期予後との相関については, モニタリングによるICP 充進抑制が生存率や神経学的転 帰を改善させている ${ }^{9)}$.

ガイドライン第 3 版公表時点では ADAPT の研究内容 
は反映されていない，しかしガイドラインは，重症頭部 外傷全症例に対し有効性が確立された治療法を紹介する ものではなく，現時点で最良と考えられている全身管理 法と数多くの外傷性脳損傷に関するエビデンスに基づい た推奨を統合したものであり, エビデンスが不十分な分 野は，本来ガイドラインが応用できる範疇ではない，将 来改訂第 3 版ガイドラインの推奨項目により, 新たな治 療戦略が開発されることを期待する。

当院ではGCS 8 以下の重症例は原則として気管挿管下 に鎮静鎮痛を図るなどガイドラインに準拠したICU管理 を実施している．持続脳波モニタリングなどを駆使し脳 損傷の解剖学的, 機能的評価を行うが, ICP センサー留 置は画像所見を基に決定， ICP 值の正常化を治療の最優 先目標とする. 入院後可及的早期よりリハビリテーショ ン部と連携し機能評価を実施している。受傷後 $1,3,6$ カ月の定点で高次脳機能評価を行い, 両親や学校と意思 疎通を図りながら可能な限り普通学級への復帰を目指し ている.

\section{虐待による頭部外傷に関する諸問題}

\section{1 はじめに}

児童相談所への虐待に関する年間相談件数は 15 万件 (2018 年度)に及んでおり, 虐待による頭部外傷 (abusive head trauma：AHT）は 2 歳以下の重症頭部外傷の原因と して最多である.AHTの多様な病態には不明な点も多 く, 再現性のある実験モデルが求められてきた。また集 学的治療にもかかわらず転帰不良であり, 神経学的後遺 症を余儀なくされることが多い。近年多施設研究により ガイドラインに準拠した治療と積極的リハビリテーショ ンが機能回復に有効と示された。また AHT に関する医 学的知見は司法判断に与える影響が大きく注目が集まっ ている.

\section{2 臨床所見}

AHT は軽症から重症まで多様な臨床像を呈し, 嘔吐, 食思不振，栄養不良など非特異的症状や，頭囲拡大，痤 攣発作, 発達遅滞など神経学的主訴で受診する場合, 兄 弟の受傷を契機に発見される場合，心肺停止例の autopsy imaging で明らかになる場合もある. 新旧混在し た紫斑や熱傷など皮膚所見は診察時に発見されることが 多く，家族から申告されることはまれである。特徵的所 見が 3 個以上認めら机た場合の診断の陽性的中率は $85 \%$ 以上といわ机る ${ }^{40)}$ 。その他，外傷の病歴がない，頭部の 外傷所見がない, 複雑な頭蓋骨骨折などは AHT の疑い
が強いとした報告もある ${ }^{29)}$.「ソファーなど低位から墜 落した」「つかまり立ちから自己転倒した」と申告される 場合もあり，慎重な判断が必要となる．乳幼児の意識レ ベルなど一般状態の異常を判断することは容易ではない ため小児科に依頼する。眼科, 整形外科的異常の判断も 専門診療科の判断を仰ぐなど組織として対応する姿勢が 重要である。

\section{3 画像診断と鑑別診断}

頭蓋・頝椎頝髄領域の CT/MRI がきわめて有用であ る. 特に 3D 再構成による頭蓋冠 CT 画像や，冠状断に よる頭頂領域の精査が望まれる ${ }^{17)}$. PECARN（The Pediatric Emergency Care Applied Research Network）などの 小児軽症頭部外傷に対する CT 適応基準を $\mathrm{AHT}$ 診断に適 用すべきではない ${ }^{39)}$.MRIによる susceptibility-weighted imaging (SWI) は $\mathrm{T} 2 *$ 強調像 $\left(\mathrm{T} 2{ }^{*} \mathrm{WI}\right)$ と同様に局所磁 場を乱す構造を強調するため, 微小出血性病変に特異度 の高い撮像法である．頭蓋外出血や脳挫傷，脳深部（基 底核や脳梁）の損傷，網膜出血を評価することができ $3^{50)}$. 硬膜下液体貯留の成分や発生時期, 架橋静脈の走 行など解剖学的考察も可能である ${ }^{53)}$.

虐待群と単純事故群の CT 画像所見の比較により, (1) 複雑な骨折パターンは虐待群に多い, (2)硬膜外血腫は事 故群に多い，(3)硬膜下血腫は虐待群に多い，(4)くも膜下 出血，脳実質内出血に有意差はないと結論された。特に 大脳鎌近傍に認められる急性硬膜下血腫はAHTに最も よくみられる所見であり，混合吸収域である場合はより 特異度が高いという ${ }^{6)}$. Bradford ら ${ }^{10)}$ は虐待による受傷 が確定した 105 例を対象とし，92\%に急性硬膜下血腫を 認めたが，初回 CTによる血腫の放射線吸収性には一定 の傾向はなく多様であるため, 受傷時期の判断は避ける よう勧告した。

脳実質損傷の描出には MRIが有用であり, 脳挫傷や微 小出血性病変といった一次性脳損傷，虚血・低酸素の影 響を受けた二次性脳損傷についても評価できる ${ }^{46)}$. Diffusion weighted imaging（DWI）による白質信号変化は, 脳動脈灌流域に拠らないため一義的に脳虚血といえな い.また静脈損傷は AHT と強く相関があるが，架橋静 脈と矢状静脈洞の結合部に最も異常が認められ硬膜下血 腫の起源と考元られている。皮質静脈損傷や脳静脈内血 栓も認められ，病理学的に硬膜内の出血所見が指摘され ている ${ }^{14)}$.

AHT を疑う場合, 頚椎・頝髄の評価も重要である。乳 児は上位䅡椎・頝髄損傷を起こしやすく，椎体や椎弓に 骨損傷を伴わず軟部組織・勒帯損傷を生じやすい ${ }^{16)}$ 。児 
童虐待疑いの乳幼児を対象とした研究では骨性の頝椎損 傷の頻度は $0.3 \sim 2.7 \%$ とされる ${ }^{30)}$. 骨損傷以外の損傷は 60 70\%であり, 勒帯損傷や軟部組織内出血, 斜台後部 硬膜外血腫の報告などがある ${ }^{15)}$. 頭蓋内損傷を認めた場 合，全椎体・脊䯣の MRI 検査が強く推奨される.

頭囲拡大を伴う乳児の良性くも膜下腔拡大（benign enlargement of sub-arachnoid spaces in infancy: BESS) は, 発生原因が明らかではない。712 例の検討では, $5.3 \%$ に硬膜下液体貯留を認め, うち 12 例が血液貯留で あった．血液成分を認めた例の $41.7 \%$ に外傷の関与が あったという ${ }^{25)}$. 現在，血液成分を伴う非血液性の液体 貯留を硬膜下に認める場合直ちに AHT と診断すること は避けられるべきである。

分婏外傷は重要な鑑別疾患であり，異常分娩後の帝王 切開や吸引・鉗子による機械分娩後，外傷性脳損傷の罹 患率は比較的高い ${ }^{51)}$ 。特に硬膜下血腫は小脳テント近傍 や後頭蓋窩に多くみられ，無症状の新生児の $8 \sim 46 \%$ に 認めた報告もある ${ }^{38)}$. 予後はきわめて良好であり, Rooks $5^{48)}$ は無症状の新生児に対し, 出生後 72 時間以内 にMRI を実施し急性硬膜下血腫を確認したが, 全例 3 力 月後に消失かつ神経学的後遺症は認めていない. 分娩外 傷とAHTとの鑑別において重要な知見である.

\section{4 病態と治療}

Hemispheric hypodensity (HH) は big black brain とも 呼称され, AHTに特徵的な CT 所見として知られる。 CT 上皮髄境界消失が大脳半球広範に及ぶ一方, 基底核は正 常に保持されるためこの所見は cortical ribbon と表現さ れる。同部位はDWI高信号を呈することから脳浮腫と解 釈できる（Fig. 3)。受傷後数時間〜数日後に認められ， 時間との明確な相関はない。従来, 脳梗塞, 虚血性低酸 素性脳症などと考えられてきたが成因については未解明 であった ${ }^{24)}$. AHT 確定診断例の 25〜 50\%に認められ, 急速に脳萎縮が進行するため HH を伴う AHT 例の死亡 率は非 HH 例の 2 倍と予後不良である ${ }^{22)}$.

Costine-Bartell ら ${ }^{19)}$ は幼弱な piglet モデルを用い, 急 性硬膜下血腫による脳実質の物理的圧迫, 頭部への衝 撃, 低換気ストレスに痤攣発作を加え病巣を再現した。 病理学的にも AHT 特有の所見の再現に成功している. AHT には疰攣重積など電気生理学的異常が $70 〜 80 \%$ と きわめて高い確率で発生することから, HH の形成に痤 攣発作が driver となることを示唆した研究である. AHT に対する神経集中治療では痤攣コントロールが非常に重 要であり, 持続脳波モニタリングによるリアルタイムの 異常検出が望ましい．積極的な抗癧攣薬投与などによる

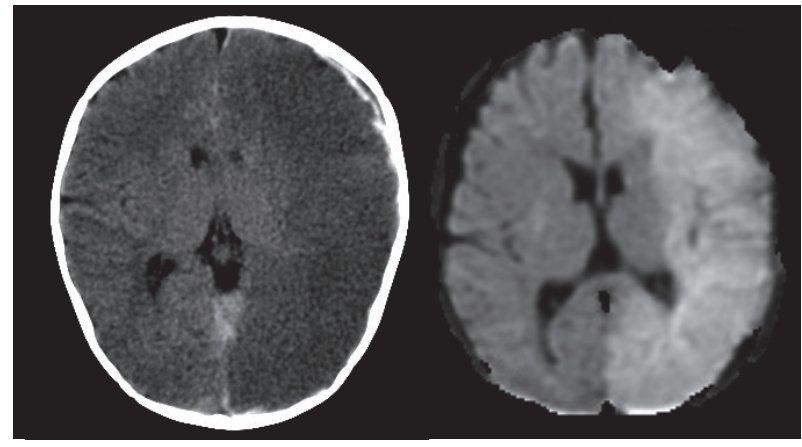

Fig. 3 Hemispheric hypodensity (HH)

A 6-month-old infant was brought to the emergency room with status epilepticus without any history of a traumatic event. Initial brain CT showed a thin acute subdural hematoma and $\mathrm{HH}$ extended on the left side. Subsequent magnetic resonance diffusion-weighted imaging showed high signal changes in the same area. Neither test showed abnormalities in the basal ganglia.

電気生理学的異常への治療は転帰改善のために推奨され $ろ^{21) 26)}$.

\section{5 転帰とリハビリテーション}

AHT 確定診断例を対象とした研究では, 剖検により広 範な脳萎縮像（multicystic encephalomalacia：MCE）が認 められ全例に硬膜下血腫が合併していた ${ }^{41)}$. AHT の長期 予後は死亡率 $20 \sim 25 \%$ ときわめて重篤であり, 精神発達 遅延や運動機能障害（痤性片麻痺・痤性対麻痺）（15～ $64 \%)$, 㗏攣 $(11 \sim 32 \%)$, 脳萎縮を伴う小頭症 $(61$ $100 \%)$, 視力障害 $(18 \sim 48 \%)$, 言語障害 $(37 \sim 64 \%)$, 認知行動異常, 睡眠障害, 知的障害, 易興奮性, 攻撃性, 注意力障害など多様な障害が存在する。予後不良因子と して, 来院時の状態（昏睡，痤攣，網膜出血，頭蓋骨骨 折，頭蓋内病変特に脳浮腫および脳萎縮）が挙げられ $3^{13)}$. 年齢別では $2 \sim 4$ 歳群のほうが 2 歳以下群より高い 死亡率であった。特にくも膜下出血, 脳浮腫, 網膜出血 の合併が死亡率に強く相関し，2歳以下では頭蓋骨骨折 と頭蓋内出血性病変が多い反面, $2 \sim 4$ 歳では体幹や内臓 器損傷, 脳浮腫が多く認められた。単純事故群との比較 では，2歳以下は AHT とほぼ同じ死亡率であったが, 2〜4 歳ではAHT による死亡率が高い ${ }^{44)}$.

長期的には発達障害の定点評価による適切なリハビリ テーション介入が重要である。教育効果は明らかに認め られ，軽症〜中等症スペクトラム児には長期観察が推奨 される ${ }^{37) 47)}$. 最重症例は ICP モニタリングを用いガイド ラインに準拠した治療による予後改善が可能である. 開 頭術は長期的神経機能改善と相関はないが，急性期り八 
Table 1 Key factors for understanding the evidence- ${ }^{-}$and consensus-based algorithm of first-tier therapies for the management of severe traumatic brain injury (TBI) in infants, children, and adolescents

Question

1. How does this algorithm work?

2. What do the solid and dotted lines mean?

3. What the dotted and dashed lines mean?

4. What should the treating physician be aware of when using algorithms for treatment?
The algorithm has 5 components, baseline care (black), intracranial pressure (ICP) pathway (yellow), brain herniation pathway (green), cerebral perfusion pressure (CPP) pathway (orange), and brain tissue partial pressure of oxygen $\left(\mathrm{PbrO}_{2}\right)$ pathway (pink). Solid lines represent the ICP and CPP pathways and dashed lines represent the $\mathrm{PbrO}_{2}$ pathway.

The dotted and dashed lines indicate withdrawal or discontinuation of the intervention.

To integrate the available information and apply the guidelines in order to create an optimal treatment strategy, always keeping in mind the patient's response to each treatment.

The "tempo" or timing of treatment implementation or withdrawal will vary depending on the case context; a single treatment intervention may be sufficient for elevated ICP, or simultaneous intervention of multiple treatments may be necessary.

If baseline care is ineffective for ICP control, the ICP and CPP pathway is advanced（solid black line).

Blue boxes indicate the need for second-tier therapy and link to Fig. 2.
ビリテーションによる予後良好例の報告も少なくない ${ }^{42)}$.

\section{AHT と発生機序研究の限界}

びまん性脳損傷の機序に関する考察は，遷延性意識障 害患者の剖検において脳表に肉眼的損傷が明らかでな かった症例の報告に由来する. Denny-Brown と Russel ${ }^{20)}$ はサルを用い頭部への鈍的外傷により脳白質内に shearing-injury が発生することを確認した. Holbourn ${ }^{27)}$ はゼ ラチンモデルを用いた実験により，衝撃による脳実質内 への shear strain が損傷を発生させる仮説を提唱した。 $\mathrm{Strich}^{49)}$ は病理学的検討を行い, 重症頭部外傷患者の剖 検において白質神経線維の断裂および retraction ball 発見した。その後 shearing injuryによる病態仮説は主流 を占め，重症のびまん性脳損傷の主病変は大脳白質を中 心とした広範な軸索損傷と考えられるようになったとい える. Adams $^{1}{ }^{1}$ は, 剖検脳の研究から, びまん性脳損傷は 転落より交通事故症例に多く認められることから，頭部 の回転加速度による shear strain を機序として提唱した。 びまん性脳損傷の病理学的所見の特徵は(1)脳梁出血およ び壊死，(2)上小脳脚付近の出血壊死，(3)軸索損傷による reactive axonal retraction ball である. Ommaya ら ${ }^{45)}$ はサ ルの頭部に回転加速度を加えた結果, 加速度の強さと意 識障害の程度に相関を示し, 病理学的にも大脳皮髄境界 や深部の出血を認めたことから, 回転加速度による shearing strain が大脳半球の広範な軸索損傷の原因と結 論した。臨床研究でも生体力学的推察の多くが承認され ていたが，近年では倫理的問題から霊長類を用いた研究 が困難となり in vitro モデルが主体となる。
AHT の構成要素として硬膜下血腫, 網膜出血, 脳浮腫 等臨床所見の科学的に妥当性については議論が続いてい るが, in vitro モデルはエビデンスレベルが低いものとな らざるを得ず，医学的因果関係を証明するには十分でな い. 脳・脊椎のみを対象とした生体力学的モデルも数学 的に不正確とならざるを得ない. AHTの受傷機転の解明 は今後も注目されるが，研究の限界が正しく認識されな くてはならない11).

\section{7 三徵候による AHT 診断に関する議論}

スウェーデン医療技術評価および医療福祉評価局 (Swedish Agency for Health Technology Assessment and Assessment of Social Services：SBU）は摇さぶり動作に よる脳損傷の医学的調査における三徵候（硬膜下血腫, 脳障害, 網膜出血) の役割について systematic review を 実施し，11三徵候や三徵候を構成する個々の所見が暴力 的摇さぶりと相関することを示す科学的根拠のレベルは いずれも低い，(2)三徵候をもつて暴力的摇さぶりの関与 を正確に証明するに十分なレベルの科学的根拠はないと 報告した ${ }^{23)}$. 中程度エビデンスレベルと判断された 2 研 究のうち Vinchon $5^{52)}$ の前向き調査は, 2 歳以下の乳児 412 例を対象とし, 虐待 124 例と単純事故 288 例の 2 群 に分類し，虐待 124 例中摇さぶりの自白を得た 45 例では 30 例で摇さぶり単独，15 例で摇さぶり以外の外力が付 加された受傷であることを明らかにした。 45 例中 37 例 （82\%）で硬膜下血腫， 44 例中 37 例（84\%）で網膜出血 を認め，脳虚血は 40 例中 12 例（27\%）に認められた。 Adamsbaum ら ${ }^{2)}$ は摇さぶり自白のある 29 例を対象とし, 
24 例 (83\%) に網膜出血を認め, 暴力的摇さぶり (100\%), 複数回の摇さぶり $(55 \%)$ の関与を報告した。 2 研究は, 暴力的摇さぶりは急性硬膜下血腫や網膜出血の原因とな り得ると結論したものの, systematic review 上エビデン スレベルの高い研究でないことから「三徵候により暴力 的摇さぶり動作の関与が正確に断定できるか」判断でき ないと結論した ${ }^{23)}$ 。これに対し共同声明により SBU 報告 書の問題点が指摘され, AHT研究の必要性と多職種によ る総合的な判断の重要性が改めて認識された ${ }^{18)}$. SBU 報 告書は虐待にかかわる司法判断に資する科学的根拠の在 り方を社会に問う役割を果たしたといえる。

本邦では軽微な受傷機転による乳幼児急性硬膜下血腫 の存在が知られる。後方転倒後, 急激な意識障害と顔面 蒼白, 四肢㾏性麻痺, 網膜出血などを伴う乳幼児急性硬 膜下血腫の疾患群であり ${ }^{43)}$, 歩行可能となる $6 \sim 10$ 力月 以降の発症が多く, 血腫は少量で予後が比較的よいこと など諸家の報告が認められるが，Aoki ら ${ }^{5)}$ が infantile acute subdural hematoma 26 例を報告し国際的にも臨床 的価値が認められている.

日本脳神経外傷学会・日本脳神経外科学会監修による 頭部外傷治療・管理のガイドライン第 4 版には，小児頭 部外傷の章「虐待による頭部外傷」の項において,「乳幼 児の急性および慢性の硬膜下血腫の解剖学的成因につい ては様々な説が存在するが, 血液凝固障害, 代謝異常, 感染症など既往歴による画像所見の解釈や，病歴の整合 性，眼科所見，過去の虐待の有無などを総合的に判断す る必要があり, 脳神経外科単科による判断は容易でな く, 行うべきではない. 院内虐待防止委員会などシステ ムとして虐待の有無について判断を行うこと, 学会が主 催する研修会への参加を通して, 虐待診断の精度を上げ るための努力が望まれる」と記載されている，現在，軽 微な受傷機転による乳幼児急性硬膜下血腫の全国調査が なされており, 本邦の悉皆調査として貴重な科学的根拠 となることが期待される。

\section{8 まとめ}

AHT の病態解明と, 神経集中治療を駆使した救命, 残 存機能に対するリハビリテーションが同期して行われる ことにより，予後改善は十分に期待できるであろう。同 時に，AHTがもたらす重大な㳖失に関する社会啓発，児 童虐待防止のための実効的施策の構築，司法判断に資す る医学的意見陳述など，多くの役割が脳神経外科に期待 されている。

日本の将来推計人口によれば， 2060 年の総人口は 8,674 万人に減少し, 65 歳以上が全人口の約 $40 \%, 18$ 歳
未満は $13 \%$ となると試算されている ${ }^{35)}$. 未来の日本を担 う大切な子どもたちは “ひとりたりとも”失われてはな らない。少頭部外傷診療を担う脳神経外科は専門診療 科として適切かつ迅速な対策を講じるための重要な役割 を果たさなくてはならない.

著者全員は日本脳神経外科学会への COI 自己申告の登録を 完了しています。本論文に関して開示すべきCOI はありませ ん.

\section{文 献}

1) Adams JH, Graham DI, Murray LS, Scott G: Diffuse axonal injury due to nonmissile head injury in humans-an analysis of 45 cases. Ann Neurol 12: 557-563, 1982.

2) Adamsbaum C, Grabar S, Mejean N, Rey-Salmon C: Abusive head trauma : judicial admissions highlight violent and repetitive shaking. Pediatrics $126: 546-555,2010$.

3) Alberico AM, Ward JD, Choi SC, Marmarou A, Young HF : Outcome after severe head injury. Relationship to mass lesions, diffuse injury, and ICP course in pediatric and adult patients. J Neurosurg 67: 648-656, 1987.

4) Alkhoury F, Kyriakides TC: Intracranial pressure monitoring in children with severe traumatic brain injury: National Trauma Data Bank-based review of outcomes. JAMA Surg 149 : 544-548, 2014.

5) Aoki $\mathrm{N}$, Masuzawa $\mathrm{H}$ : Infantile acute subdural hematoma. Clinical analysis of 26 cases. J Neurosurg $61: 273-280$, 1984.

6) Bechtel K, Stoessel K, Leventhal JM, Ogle E, Teague B, Lavietes S, Banyas B, Allen K, Dziura J, Duncan C : Characteristics that distinguish accidental from abusive injury hospitalized young children with head trauma. Pediatrics 114: 165-168, 2004.

7) Bell MJ, Adelson PD, Hutchison JS, Kochanek PM, Tasker RC, Vavilala MS, Beers SR, Fabio A, Kelsey SF, Wisniewski SR; Multiple Medical Therapies for Pediatric Traumatic Brain Injury Workgroup : Differences in medical therapy goals for children with severe traumatic brain injury-an international study. Pediatr Crit Care Med 14:811-818, 2013.

8) Bell MJ, Adelson PD, Wisniewski SR ; Investigators of the ADAPT Study : Challenges and opportunities for pediatric severe TBI-review of the evidence and exploring a way forward. Childs Nerv Syst $33:$ 1663-1667, 2017.

9) Bennett TD, Riva-Cambrin J, Keenan HT, Korgenski EK, Bratton SL: Variation in intracranial pressure monitoring and outcomes in pediatric traumatic brain injury. Arch Pediatr Adolesc Med 166: 641-647, 2012.

10) Bradford R, Choudhary AK, Dias MS : Serial neuroimaging in infants with abusive head trauma : timing abusive injuries. J Neurosurg Pediatr 12:110-119, 2013.

11) Castellani RJ, Schmidt CJ: Brain injury biomechanics and abusive head trauma.J Forensic Sci Med 4: 91-100, 2018.

12) Chesnut RM, Temkin N, Carney N, Dikmen S, Rondina C, Videtta W, Petroni G, Lujan S, Pridgeon J, Barber J, Machamer J, Chaddock K, Celix JM, Cherner M, Hendrix T ; Global Neurotrauma Research Group : A trial of intracranial-pressure monitoring in traumatic brain injury. $N$ Engl $J$ 
Med 367:2471-2481, 2012.

13) Chevignard MP, Lind $K$ : Long-term outcome of abusive head trauma. Pediatr Radiol 44 Suppl 4: S548-558, 2014.

14) Choudhary AK, Bradford R, Dias MS, Thamburaj K, Boal $\mathrm{DKB}$ : Venous injury in abusive head trauma. Pediatr Radiol 45 : 1803-1813, 2015.

15) Choudhary AK, Bradford RK, Dias MS, Moore GJ, Boal DKB : Spinal subdural hemorrhage in abusive head trauma : a retrospective study. Radiology 262:216-223, 2012.

16) Choudhary AK, Ishak R, Zacharia TT, Dias MS : Imaging of spinal injury in abusive head trauma : a retrospective study. Pediatr Radiol 44:1130-1140, 2014.

17) Choudhary AK, Jha B, Boal DK, Dias M : Occipital sutures and its variations : the value of $3 \mathrm{D}-\mathrm{CT}$ and how to differentiate it from fractures using 3D-CT? Surg Radiol Anat 32: 807-816, 2010.

18) Choudhary AK, Servaes S, Slovis TL, Palusci VJ, Hedlund GL, Narang SK, Moreno JA, Dias MS, Christian CW, Nelson MD Jr, Silvera VM, Palasis S, Raissaki M, Rossi A, Offiah $\mathrm{AC}$ : Consensus statement on abusive head trauma in infants and young children. Pediatr Radiol 48:1048-1065, 2018.

19) Costine-Bartell BA, McGuone D, Price G, Crawford E, Keeley KL, Munoz-Pareja J, Dodge CP, Staley K, Duhaime $\mathrm{AC}$ : Development of a model of hemispheric hypodensity (“Big Black Brain”). J Neurotrauma 36:815-833, 2019.

20) Denny-Brown D, Russel WR : Experimental cerebral concussion. Brain $64:$ 93-164, 1941.

21) Dingman AL, Stence NV, O’Neill BR, Sillau SH, Chapman $\mathrm{KE}$ : Seizure severity is correlated with severity of hypoxic-ischemic injury in abusive head trauma. Pediatr Neurol 82: 29-35, 2018.

22) Duhaime AC, Durham S: Traumatic brain injury in infants : the phenomenon of subdural hemorrhage with hemispheric hypodensity ("Big Black Brain"). Prog Brain Res 161 : 293-302, 2007.

23) Elinder G, Eriksson A, Hallberg B, Lynøe N, Sundgren PM, Rosén M, Engström I, Erlandsson BE : Traumatic shaking : The role of the triad in medical investigations of suspected traumatic shaking. Acta Paediatr 107 Suppl 472:3-23, 2018.

24) Foster KA, Recker MJ, Lee PS, Bell MJ, Tyler-Kabara EC : Factors associated with hemispheric hypodensity after subdural hematoma following abusive head trauma in children. $J$ Neurotrauma 31: 1625-1631, 2014.

25) Hansen JB, Frazier T1, Moffatt M, Zinkus T, Anderst JD : Evaluations for abuse in young children with subdural hemorrhages : findings based on symptom severity and benign enlargement of the subarachnoid spaces. J Neurosurg Pediatr $21: 31-37,2018$.

26) Hasbani DM, Topjian AA, Friess SH, Kilbaugh TJ, Berg RA, Christian CW, Dlugos DJ, Huh J, Abend NS : Nonconvulsive electrographic seizures are common in children with abusive head trauma*. Pediatr Crit Care Med 14:709-715, 2013.

27) Holbourn AHS : Mechanics of head injuries. Lancet 242 : 438-441, 1943.

28) Jagannathan J, Okonkwo DO, Yeoh HK, Dumont AS, Saulle D, Haizlip J, Barth JT, Jane JA Sr, Jane JA Jr : Long-term outcomes and prognostic factors in pediatric patients with severe traumatic brain injury and elevated intracranial pres- sure. J Neurosurg Pediatr 2 : 240-249, 2008.

29) Kelly P, John S, Vincent AL, Reed P : Abusive head trauma and accidental head injury: a 20-year comparative study of referrals to a hospital child protection team. Arch Dis Child 100 : 1123-1130, 2015.

30) Kemp A, Cowley L, Maguire S : Spinal injuries in abusive head trauma : patterns and recommendations. Pediatr Radiol 44 Suppl 4: S604-612, 2014.

31) K Kochanek PM, Carney N, Adelson PD, Ashwal S, Bell MJ, Bratton S, Carson S, Chesnut RM, Ghajar J, Goldstein B, Grant GA, Kissoon N, Peterson K, Selden NR, Tasker RC, Tong KA, Vavilala MS, Wainwright MS, Warden CR ; American Academy of Pediatrics-Section on Neurological Surgery; American Association of Neurological Surgeons/ Congress of Neurological Surgeons ; Child Neurology Society; European Society of Pediatric and Neonatal Intensive Care; Neurocritical Care Society; Pediatric Neurocritical Care Research Group; Society of Critical Care Medicine; Paediatric Intensive Care Society UK ; Society for Neuroscience in Anesthesiology and Critical Care ; World Federation of Pediatric Intensive and Critical Care Societies: Guidelines for the acute medical management of severe traumatic brain injury in infants, children, and adolescents - second edition. Pediatr Crit Care Med 13 (Suppl 1) : S1-S82, 2012.

32) Kochanek PM, Tasker RC, Bell MJ, Adelson PD, Carney N, Vavilala MS, Selden NR, Bratton SL, Grant GA, Kissoon N, Reuter-Rice KE, Wainwright MS : Management of pediatric severe traumatic brain injury : 2019 consensus and guidelines-based algorithm for first and second tier therapies. Pediatr Crit Care Med 20: 269-279, 2019.

33) Kochanek PM, Tasker RC, Carney N, Totten AM, Adelson PD, Selden NR, Davis-O'Reilly C, Hart EL, Bell MJ, Bratton SL, Grant GA, Kissoon N, Reuter-Rice KE, Vavilala MS, Wainwright MS : Guidelines for the management of pediatric severe traumatic brain injury, third edition : update of the Brain Trauma Foundation Guidelines. Pediatr Crit Care Med 20 (3S Suppl 1) : S1-S82, 2019.

34) Kochanek PM, Tasker RC, Carney N, Totten AM, Adelson PD, Selden NR, Davis-O'Reilly C, Hart EL, Bell MJ, Bratton SL, Grant GA, Kissoon N, Reuter-Rice KE, Vavilala MS, Wainwright MS : Guidelines for the management of pediatric severe traumatic brain injury, third edition : update of the Brain Trauma Foundation Guidelines, executive summary. Pediatr Crit Care Med 20:280-289, 2019.

35）国立社会保障 - 人口問題研究所：人口問題研究資料第 336 号 日本の将来推計人口一平成 28 (2016) ～77 (2065) 年一。 2017.

http://www.ipss.go.jp/publication/j/shiryou/jinkoken shiryou.html

36) Kurz JE, Poloyac SM, Abend NS, Fabio A, Bell MJ, Wainwright MS ; Investigators for the Approaches and Decisions in Acute Pediatric TBI Trial: Variation in anticonvulsant selection and electroencephalographic monitoring following severe traumatic brain injury in children-understanding resource availability in sites participating in a comparative effectiveness study. Pediatr Crit Care Med 17:649-657, 2016.

37) Lind K, Toure H, Brugel D, Meyer P, Laurent-Vannier A, Chevignard $\mathrm{M}$ : Extended follow ${ }^{-}$up of neurological, cognitive, behavioral and academic outcomes after severe abusive head trauma. Child Abuse Negl $\quad 51$ : 358-367, 2016. 
38) Looney CB, Smith JK, Merck LH, Wolfe HM, Chescheir NC, Hamer RM, Gilmore JH : Intracranial hemorrhage in asymptomatic neonates: prevalence on MR images and relationship to obstetric and neonatal risk factors. Radiology 242: 535-541, 2007.

39) Magana JN, Kuppermann N : The PECARN TBI rules do not apply to abusive head trauma. Acad Emerg Med 24:382384, 2017.

40) Maguire SA, Kemp AM, Lumb RC, Farewell DM : Estimating the probability of abusive head trauma : a pooled analysis. Pediatrics 128: e550-e564, 2011.

41) Matlung SE, Bilo RA, Kubat B, van Rijn RR: Multicystic encephalomalacia as an end-stage finding in abusive head trauma. Forensic Sci Med Pathol $7:$ 355-363, 2011.

42) Miller-Ferguson N, Sarnaik A, Miles D, Shafi N, Peters MJ, Truemper E, Vavilala MS, Bell MJ, Wisniewski SR, Luther JF, Hartman AL, Kochanek PM ; Investigators of the Approaches and Decisions in Acute Pediatric Traumatic Brain Injury (ADAPT) Trial: Abusive head trauma and mortality - an analysis from an international comparative effectiveness study of children with severe traumatic brain injury. Crit Care Med $45:$ 1398-1407, 2017.

43）中村紀夫, 小林茂, 平川公義, 山田 久, 神保 実: 小児の頭部外傷と頭蓋内血腫の特徵，第 2 報 急性・亜 急性頭蓋内血腫. Brain Nerve 17:785-794， 1965.

44) Nuño M, Ugiliweneza B, Bardini RL, Oztruk A, Stephenson JT, Magaña JN : Age-related mortality in abusive head trauma.J Trauma Acute Care Surg 87:827-835, 2019.

45) Ommaya AK, Carrao P, Letcher FS : Head injury in the chimpanzee. 1. Biodynamics of traumatic unconsciousness 1. Biodynamics of traumatic unconsciousness. J Neurosurg
39: 152-166, 1973.

46) Orru' E, Huisman TAGM, Izbudak I : Prevalence, patterns, and clinical relevance of hypoxic-Ischemic injuries in children exposed to abusive head trauma. J Neuroimaging 28: 608-614, 2018.

47) Risen SR, Suskauer SJ, Dematt EJ, Slomine BS, Salorio $\mathrm{CF}$ : Functional outcomes in children with abusive head trauma receiving inpatient rehabilitation compared with children with nonabusive head trauma. J Pediatr 164:613619.e1-2, 2014.

48) Rooks VJ, Eaton JP, Ruess L, Peterman GW, Keck-Wherley $\mathrm{J}$, Pedersen RC: Prevalence and evolution of intracranial hemorrhage in asymptomatic term infants. AJNR Am J Neuroradiol 29: 1082-1089, 2008.

49) Strich SJ : Shearing of nerve fibres as a cause of brain damage due to head injury: A Pathological study of twenty cases. Lancet 278: 443-448, 1961.

50) Thamburaj K, Soni A, Frasier LD, Tun KN, Weber SR, Dias $\mathrm{M}$ : Susceptibility-weighted imaging of retinal hemorrhages in abusive head trauma. Pediatr Radiol $\quad 49: 210-216,2019$.

51) Towner D, Castro MA, Eby-Wilkens E, Gilbert WM : Effect of mode of delivery in nulliparous women on neonatal intracranial injury. N Engl J Med 341 : 1709-1714, 1999.

52) Vinchon M, de Foort-Dhellemmes S, Desurmont M, Delestret I : Confessed abuse versus witnessed accidents in infants : comparison of clinical, radiological, and ophthalmological data in corroborated cases. Childs Nerv Syst $\mathbf{2 6}$ : 637-645, 2010.

53) Zuccoli G, Khan AS, Panigrahy A, Tamber MS : In vivo demonstration of traumatic rupture of the bridging veins in abusive head trauma. Pediatr Neurol $\quad \mathbf{7 2}:$ 31-35, 2017.

\section{荒木 尚 熊井戸邦佳 大宅 宗一 庄島 正明 松居 徹}

外傷性脳損傷は, 小児年齢における罹患や死亡の重要な原因の 1 つである. 適切な治療が施された 後も, 高次脳機能障害による学業成績の支障, 健康関連 QOL の障害, 精神衛生上の問題を抱えやす く, 子ぞもの人生において外傷性脳損傷がもたらす影響は長く, 甚大である. 一方, 小児の外傷性脳 損傷に特有の病態生理学的特徵については未解明の部分も多く, エビデンスレベルの高い臨床研究や 中枢神経の成長や発達を考慮した基礎研究も少ない，成人デー夕を直線的に流用することなく小児特 有の知見を明らかにするには，今後国際的な取り組みが必要となるであろう. 小児頭部外傷における 現状と課題のうち, 急性期治療の最新知見として, 米国小児重症頭部外傷治療・管理のガイドライン 改訂第 3 版の重要ポイントを紹介する．また最新の課題として，世界的規模で深刻な社会問題となっ ている「虐待による頭部外傷 (abusive head trauma：AHT)」の診断に関する問題点と, AHTに対す る治療の可能性について解説する. 